\title{
Transforming the Almajiri Education for the Benefit of the Nigerian Society
}

\author{
Fowoyo Joseph Taiwo \\ School of Education, Federal College of Education, Kontagora, Niger State, Nigeria
}

\begin{abstract}
Almajiri or scholars in the Islamic religion has become a matter of sad concern for the North and the Nigerian nation. These children of school age and above roam about the streets in tattered clothes begging scavenging and doing all sort of odd jobs. This paper examined the Almajiri Syndrome in Nigeria, its background, nature, scope, problems and suggesting possible recommendations has to how it can move out of its present precarious situation and probably how it can contribute to meaningful developments in our nation. It was concluded that the government should enforce the 2003 Child Right Act, it was also recommended that, if the almajiri schools are properly funded most of the problems and the quantum of violence being perpetuated all over the country today will be a thing of the past.
\end{abstract}

Keywords: Islamic religion; Almajiri Syndrome; Nigerian nation

\section{INTRODUCTION}

They are abound in all the cities, towns and villages in the Northern part of Nigeria, even now their presences is being felt in the other parts of the country. They sleep in the outhouse or on veranda of the dilapidated houses which also serve as their schools or classes in the day time. Every day they are seen carrying plastic bowls, dressed in tattered clothes and mostly without shoes begging. They are pupils of Islamic knowledge known and referred to as Almajiri.

\section{THE BACKGROUND HISTORY OF THE ALMAJIRI}

The word almajiri as written by Kabiru (2012) quoting Sheik Abba Aji, a renowned Maiduguri-based Islamic scholar, is a word borrowed from Arabic language which was derived from the word 'Al-Muhajir' meaning a seeker of Islamic knowledge. Its origin was the migration of Prophet Mohammed from Mecca to Medina. Those who migrated with the prophet to Medina were called 'Al-Muhajirrun', meaning emigrants. These emigrants had no means of livelihood on getting to Medina, but based on the fraternity established by the prophet, between their hosts and them, were co-opted into different trades and vocations as apprentices who were paid for their services.

The Islamic religion came to Nigeria via the North; Fafunwa (1974) recorded that, 'Islam was brought to Hausaland in the early fourteenth century by traders and scholars. About forty Wangarawa traders were thought to be responsible for introducing Islam to Kano...during the reign of Yaqub (1452 - 63) some Fulani scholars migrated to Kano, bringing with them books 
on Islamic theology and jurisprudence. During the reign of Muhammad Rumfa (1463-99) Islam became firmly rooted and Islamic principles were taught in different places. It was during this period that Muslim scholars from Timbuktu came to Kano to teach and preach Islam.'

Armed with the Islamic Tradition which states that, 'the best man among you is one learns Quran and then cares to teach it, as written by Fafunwa, Islam gradually spred in the north and to the other parts of the country. The system of teaching and learning Quran and Arabic started from the Northern Nigeria where the teachers dependend on charity (sadakah). Fafunwa observed that this noble principle which was successfully applied in the early stage of the development of Islamic Education reduced the status of the teacher to that of a mere begger.'

Abdul Qadir (2003), presented that, The British invaded the region and killed most of the Emirs and disposed some. The Emirs lost control of their territories and accepted their new roles, as mere traditional rulers. They also lost fundamental control of the Almajiri system. The British deliberately abolished state funding in respect to the system arguing that, they were religious schools. With loss of support from the government, its immediate community and the helpless Emirs, the Almajiri system collapsed like a pile of cards. Karatun Boko, western education was introduced and funded instead. The pupils now turned, Almajirai together with their Mallams, having no financial support resorted to begging and other menial jobs for survival. This is certainly the genesis of the predicament of the Almajiri system today.

Hence begging became the order of the day. This was not meant to be as Islam frowns at begging in any form because it reduces a Muslim's self-esteem and dignity. Yet parents release their children to undergo this horrific condition out of poverty. Kabiru expressed that, 'almajiri pupils learn the Quran under a teacher three times a day without good shelter, food or good health care and away from their parents, some of whom are hundreds of kilometres away. His consolation lies in the belief that his suffering in the world is for the reward that awaits him in heaven. There is no specific age of enrolment in the almajiri school, but the duration of study depend on the academic ability of the student, what is important is the memorization of the Quran, which is in three stages, these are; (i), learning the Quran by heart (Tilawa), ii, memorising (Hafizi) and iii perfecting the ability to write the whole Quran with no error either on a slate or in a paper, (Darasi).

\section{THE LIVING CONDITION OF THE ALMAJIRI IN NIGERIA}

The almajiri are children living under a horrific condition, few of them do not know their homes or who their parents are as they are left early in life. These children had no option than to follow other group of children that came their way. This group of children are normally under a teacher (mallam) who is vast in the Islamic knowledge. In the mornings, they are seen following a bean cake (kose) seller who approaches a buyer to buy her kose and distribute it as sadakah (gift offering) to these children. In most cases these children population is large and their mallam (teacher) will have no option than to send them out to beg.

A very pathetic aspect of their lifes is what they eat, they do not care about the nature of the food cooked, fresh or stale and it can be picked from anywhere. From their appearance too they rarely take their bath. It is surprising however to see that they rarely fall sick. Kabiru (2012) quoted Abdulkareem Kwando a medical doctor as saying that, "the condition under which these street urchins lives makes them to develop very strong immunity to illnesses and diseases, which baffle medical practitioners.' They are growing in geometrical progression a 
population too large for individuals to handle; this has led the Quranic education system into a modern form of slavery and unimaginable child abuse.

\section{NEGLIGENCE BY THE GOVERNMENT}

A recent report has it that, there are more than 10 million almajiris on the streets of northern Nigeria, without formal education and invariably going to face a bleak future. The government and people of the north have left this situation to continue probably due to what many of them derived from it. In their thinking, the education of many is the liberation of all, a situation which will create competition and which will make them loose their exalted positions, as such these children are neglected and even subjected to all sort of ill treatment.

It is in a bead to protect their autocratic and feudal style in the struggle to protect their political class and style of living that has led to this modern day monster. Taiwo (2006) lamented that, 'if basic education is only available for the children of rich parents, it means the children of poor parents who cannot afford exorbitant school fees will not be able to have access to basic education. One may wonder what the attitudes of poor parents and their children would be towards the rich parents and their children.'

Today, a huge problem has been created and has even gained international recognition and support. Unfortunately a monster when created and perfected, it will never know its creator or victims, it destroys whatever comes its way.

\section{GOVERNMENT INTERVENTION}

Nigeria is a nation that value and has embraced education for a very long time. She has committed a large chunk of her earnings to the pursuance of education at all levels and has adopted education as an instrument per excellence. The government is of the hope that for the benefit of all citizens, the country's education goals shall be clearly set out in terms of their relevance to the realities of our environment and the modern world. FGN (2004) 'every Nigerian child shall have a right to equal educational opportunities irrespective of any real or imagined disabilities each according to his or her ability'.

The policy on education in Nigeria has always meant well for the development of both the individual and the nation at large; different regimes (uniformed and civilian) have pursued educational programmes with vigour. It is on record that Northerners has ruled this country longer period than the rest part of the country. Why have they delayed in incorporating almajiri education into the formal education system? Even the UBE scheme which focused on the education of the various segments of the less privileged Nigerians did not quite address the integration of the almajiri system into the Western education.

Successful northern rulers did not envisage that the neglect of this teaming almajiri population could and would become a menace and a thing of national disgrace in the future.

Recently there is a sudden renewed interest in the almajiri syndrome and the need to integrate them into the formal school system. The Nigerian government formally signed into law almajiri education on the $10^{\text {th }}$ April 2012. In his presentation to the National Economic Council in July 2013, the minister of state for Education, Ezenwo N. Wike, wrote that:

To ensure that Almajiris are provided with opportunities for access to Basic Education 

A) Federal Government set up the National Committee on Implementation of Almajiri Education Programme
B) The Committee is charged with integrating the Almajiris into the UBE Programme without prejudice to acquiring a sound mastery of Qur'anic knowledge
C) The programme is to help in the acquisition of skills to enable them participate more actively in society $\backslash$
D) The Almajiri Education Programme is in line with the Transformation Agenda of the administration under President Goodluck Ebele Jonathan, GCFR
E) The Transformation Agenda has a key component on Education and Human Capital Development
F) The 4-Year Strategic Plan for the Development of the Education Sector: 2011-
2015 has been developed to actualize the Transformation Agenda
G) The Almajiri Education Programme is concerned with Access to Quality
Education; which are the two strategic goals of Nigerian Education

\section{SUSTAINING THE ALMAJIRI SCHOOL PROGRAMME}

On the $10^{\text {th }}$ of April, 2012, the president, Dr. Goodluck E. Jonathan took a bold step by formally undertaking a pragmatic move towards the reformation of the almajiri schools in Nigeria, we became the first among the West African Countries to formally give a serious and practical approach to the integration of the almajiri school into the formal school system. This is a welcome development as the population of abandoned and underfeed children roaming about our streets will be given a transformed future. The occasion which took place at an Almajiri Model School, Gagi, Sokoto State, brought the actualization of the age long dream of the almajiri modern school system. The president declared that this programme will cover the 9.5 million almajiri population scattered across the Northern states. He added also that the school would provide the children with a conventional quality education as envisaged under his administrations education policy thrust. Expressing their observation on UPE, Fafunwa (1974) and Taiwo (1980) wrote that, the previous education scheme or programme failed due to factors such as poor planning; lack financial support, mismanagement of resources allocated to such programmes; changes in Government; inconsistence on the part of policy makers and implementation; lack of monitoring and evaluate mechanism as well as supervision. Alechenu (2012) wrote that, 'the challenges of the initiative borders on political will of the governors of beneficiary states. How well these chief executives will run the Federal Government idea which ought to have been theirs in the first place remains to be seen'.

In Okoro's (2012) view, 'it is pertinent to note that the various state and local governments over the years have note paid any attention to this group of-out-of school children in spite of the explicit provisions of the National Policy on Education and the Universal Basic Education Act. I hope this effort by the Federal Government will act as a wake-up call for them as well as motivates the states and Local Governments concerned to stamp their imprint on this project'. To buttress the above, Niraland forum (2010) quoted Salisu Tambuwal a Zamfara based Islamic scholar that he (Salisu), reads hypocrisy into the supposed efforts of the northern governors. He says, 'For the nine years some impact should have been made in the area of poverty alleviation, which is the root cause of this problem. There is no sincerity in their hearts because if they eradicate the problem, there will be no place for them to recruit political thugs.'

The foundation for human transformation and development is education, Wikipedia dictionary defined education as 'the means through which the aims and habits of a group of 
people lives on from one generation to the next. Education is the formal process by which society deliberately transmits its accumulated knowledge, skills, customs and value from one generation to another, e.g. instruction in schools.'

The above definition clearly portrays education as an activity that is functional within the life of a nation or people. Awolowo has quoted by Enoch (1996), saw 'education as a systematic course of instruction, giving intellectual and moral training to persons, bringing up of the young, helping the young to develop, to lead out the best in him to evolve an integral personality.'

The integration of the almajiri education into the formal school system is on its way to fulfil the above definition and views on education. Niraland forum suggested that, "these schools (almajiri schools) must also teach these children essential skills such as basic Arithmetic and English language which they would need to function in the wider world'. Okoro (2012) wrote that:

Originally too, the almajiri system was designed to build in young minds, sounds doctrine of Islam as specified in the holy Quran. Essentially, it was meant to teach children basic spiritual, moral and social value in order to enhance their sense of responsibility. It was also meant to inculcate in them the value of caring for those in need. Unfortunately, these esteemed goals have been defeated over the years by some dubious and modern-day Islamic scholars, who superintend over these unfortunate children.

From the above view, a modern almajiri school system will complement the existing local structure of the Islamic almajiri education. The pupils will have the opportunity of having a broaden outlook and exposure to life, its values, awareness and respect to other peoples culture and tradition. It will enhance the development of their Psychic to tolerate others and their different religions. It will serve as a ground for the correction of wrong indoctrination and manipulation. This modern almajiri schools will be a breeding ground for the training and making of future Nigerian political leaders, engineer, doctors, lawyers, teachers and expert in all other field of human endeavours. Fowoyo (2010) observed that, 'educated and enlightened citizen are easy to rule and govern because they would realise and appreciate the effort of the government and make meaningful contributions to assist her'. In a tranquil atmosphere, people will develop their abilities, potentials and express freely the creativity in them.

If the issue of these nearly ten million almajiris, whose population continues to grow, is adequately addressed our country will witness a positive and prosperous transformation. However, the government should be mindful of their responsibilities to other children in the other parts of the country, as the neglect of one part will give rise to more pandemonium being presently experienced in the country.

\section{CONCLUSION}

The minister of education, Prof. Rukayyatu Ahmed Rufai was quoted by Abdullahi (2012) as saying, "other almajiri schools would be ready for commissioning soon while assuring that the school would be equipped with basic facilities to promote the learning of Islamic religious knowledge and Western education". This statement is an indication that the almajiri schools have come to stay but the government should take a step further by enforcing the $31^{\text {st }}$ July 2003 child Rights Act. Most especially in the northern states, that is yet to pass it into law. Under this Act, children are guaranteed free and compulsory Primary education, an encouragement of secondary and tertiary education. It also guarantees children protection 
against sale, hire or use for the purpose of hawking, begging for alms, prostitution and/or use in other criminal activities.

Public media houses should be used to reach and enlighten parents so as to disabuse their erroneous believe that sending their children to school will make them lose their Islamic tenet and values. Also a programme as laudable as this should not be left in the hands of those whose interest is what they will benefit and not its development. Sustaining the programme should therefore be paramount in the mind of the northern state governors and their successors.

\section{Recommendations}

To ensure the success of the almajiri school programme, the following are recommend: Funding should be adequate, regular and monitored. The school curriculum should be planned to include technical; and vocational courses. Its long objectives should be for self sufficiency and sustenance (self employment). Adult and technical education should be put in place to cater for older ones. There should be constant supervision and monitoring of these schools' programmes and curriculum so as to check negative instructions and indoctrination. Special training should be organized for the Almajiri mallams (teachers), to give them sense of belonging, direction and to absorb them into the formal school system. Opportunities for those among them who may want to further their studies at the tertiary level should be made available.

\section{References}

[1] Abdullahi M. (2012). The almajiri: Nigeria child beggar. Africaloutlookonline.com

[2] Abdul Qadir I. A. (2003). The almajiri system of education in Nigeria today. www, gamji.com/index.php/SJPAS/article/view/637, Presented at the $21^{\text {st }}$ Convocation of Bayero University Kano.

[3] Alechenu J. (2012). Odds against the almajiri education. www.punchng.com $>$ Education.

[4] Enoch O. (1996). Main currents in Nigerian educational thought. Jos: mid-land press, Nigeria ltd.

[5] Fafunwa A. B. (1974). History of education in Nigeria. London: George Allen and Unwin ltd. Pp. 50 - 55.

[6] Federal Republic of Nigeria (2004). National Policy on Education. Lagos: NERDC Press.

[7] Fowoyo J. T. (2010). Fundation of pre-primary and primary education studies; a handbook for students, Kontagora: Sunny - tex printers. Pp 36.

[8] Kabiru I. (2010). The north and almajiri phenomenon. www.gamji.com/article8000/NEWS8282.htm.

[9] Niraland Froum (2010). www.nairaland.com/836120/almajiri-breeding-futureTerrorists $10: 37 \mathrm{pm}$ on Jan 22, 2010

[10] Okoro D. (2012). Concretising the almajiri education policy in Nigeria. Punch newspaper: www.punching.com/------/universal-basic-education-act-and-the-almajiri

[11] Taiwo B. M. (2006). Universal basic education: a means of achieving peace and National Unity in Nigeria. In Kontagora journal of education, vol. 8, pp. $67 \& 80$.

[12] Wikipedia Dictionary (2009). Microsoft Encarta premium.

[13] Tomáš Hes, Anna Poledňáková, International Letters of Social and Humanistic Sciences 2 (2013) 18-31.

[14] Mohsen Mehrara, Masoumeh zirak, International Letters of Social and Humanistic Sciences 2 (2013) 32-38. 
[15] Taiwo Adewale Muritala, Ismail O. Fasanya, International Letters of Social and Humanistic Sciences 2 (2013) 39-50.

[16] Borowski A., International Letters of Social and Humanistic Sciences 3 (2013) 46-53.

[17] Borowski A., International Letters of Social and Humanistic Sciences 3 (2013) 69-74.

[18] Donovan A. McFarlane, International Letters of Social and Humanistic Sciences 4 (2013) 35-44.

[19] Rajesh K. Yadav, Nishant Dabhade, International Letters of Social and Humanistic Sciences 4 (2013) 49-69.

[20] Borowski A., International Letters of Social and Humanistic Sciences 4 (2013) 70-74.

[21] Paul Bukuluki, International Letters of Social and Humanistic Sciences 5 (2013) 27-44.

[22] Mohsen Mehrara, Maysam Musai, International Letters of Social and Humanistic Sciences 5 (2013) 55-62.

[23] Debiprasad Mukherjee, International Letters of Social and Humanistic Sciences 6 (2013) 41-48.

[24] Tomáš Hes, Alena Neradová, Karel Srnec, International Letters of Social and Humanistic Sciences 7 (2013) 55-75.

[25] Kinga Dziwańska, International Letters of Social and Humanistic Sciences 7 (2013) 96-112.

[26] Borowski A., International Letters of Social and Humanistic Sciences 7 (2013) 113-118.

[27] Mohsen Mehrara, Maysam Musai, International Letters of Social and Humanistic Sciences 8 (2013) 1-7.

[28] Tittenbrun J., International Letters of Social and Humanistic Sciences 11 (2013) 10-34.

[29] Mohsen Mehrara, Hamid Abrishami, Mostafa Boroujli, Mahan Amin, International Letters of Social and Humanistic Sciences 11 (2013) 76-83.

[30] Borowski A., International Letters of Social and Humanistic Sciences 11 (2013) 100-105.

[31] Morteza Amani, Mahmood Goodarzi, Hamze Ahamadian, International Letters of Social and Humanistic Sciences 1 (2014) 7-13.

[32] Seyed Mohammad Marandi, Hossein Pirnajmuddin, International Letters of Social and Humanistic Sciences 1 (2014) 14-27.

[33] Elias Olukorede Wahab, Chioma Joan Ikebudu, International Letters of Social and Humanistic Sciences 1 (2014) 28-42.

[34] Bahram Meihami, Zeinab Varmaghani, Hussein Meihami, International Letters of Social and Humanistic Sciences 1 (2014) 43-5.

[35] Francis Briggs, Elizabeth Desmond, International Letters of Social and Humanistic Sciences 1 (2014) 71-80.

[36] Liverpool E. Onyije, Jacinta A. Opara, International Letters of Social and Humanistic Sciences 1 (2014) 81-87

[37] Sele Sylvester Ebisin, International Letters of Social and Humanistic Sciences 2 (2014) $1-9$.

[38] Tittenbrun J., International Letters of Social and Humanistic Sciences 2 (2014) 20-40.

[39] Borowski A., International Letters of Social and Humanistic Sciences 2 (2014) 110-121.

[40] Pawa Tersoo, International Letters of Social and Humanistic Sciences 3 (2014) 26-36.

[41] Rabi'u Muhammad Ishaq, International Letters of Social and Humanistic Sciences 3 (2014) 37-44. 
[41] Adoga James Ada, International Letters of Social and Humanistic Sciences 3 (2014) 45-52.

[42] Bahram Meihami, Hussein Meihami, International Letters of Social and Humanistic Sciences 3 (2014) 80-91.

[43] Kabiru Ibrahim Yankuzo, International Letters of Social and Humanistic Sciences 4 (2014) 1-8.

[44] Onyike Maggaret Odu, International Letters of Social and Humanistic Sciences 4 (2014) 31-39.

[45] Uloma Charity Oguzor, International Letters of Social and Humanistic Sciences 4 (2014) 97-104.

[46] Okezie A. Ihugba, Alex Odii, A. C. Njoku, International Letters of Social and Humanistic Sciences 5 (2014) 21-34.

[47] Okezie A. Ihugba, Bankoli Bankong, N. C. Ebomuche, International Letters of Social and Humanistic Sciences 5 (2014) 92-113.

[48] Borowski A., International Letters of Social and Humanistic Sciences 6 (2013) 86-90.

[49] Borowski A., International Letters of Social and Humanistic Sciences 3 (2013) 69-74. 